\title{
GUIDE TO THE INTERNATIONAL ARCHIVES AND COLLECTIONS AT THE IISH: SUPPLEMENT OVER 2002*
}

In 2000 a new edition of the 'Guide to the International Archives and Collections at the IISH, Amsterdam' (henceforth cited as GIA) was published. A description of recently acquired archives and collections as well as major accruals to archives received by the IISH will be published annually to keep this survey up to date. Like the GIA this supplement is subdivided into the categories 'persons', 'organizations' and 'subjects', arranged alphabetically.

As to the summaries the following components can be discerned:

I. Access. As a rule consultation is not restricted; any restrictions are indicated by *

2. Name. Names of persons include dates of birth and death when known. In the case of international organizations with names in more than one language, the name chosen corresponds to the language in which most of the documents were written. Among organizations that have changed their names, the one used most recently was selected. Previous names of organizations are mentioned in the condensed biography or history. The names of subject collections are mostly in English.

3. Period. First and last date of the documents present. Where only a few documents are from a certain year or period, they are listed between parentheses.

4. Size. In linear metres.

5. Finding aid. Available inventories (published and unpublished), lists and indexes.

6. Biography/history. A condensed biography or history of the persons or organizations concerned.

7. Summary of the contents. A summary of the contents of the archives, papers or collection concerned.

Reference is given to the pages of the GIA holding the initial description where summaries of an accrual are concerned.

The summaries of this supplement will also be added to the survey of archival collections on the Internet website of the IISH (http://www.iisg.nl). Summaries of the Dutch collections of the IISH can be found in the survey on the Internet website too.

The archives may be consulted in the reading room of the IISH. Requests for documents should include their inventory or list numbers. For further information about the rules for access and consultation (including rules on procedures for handling the material and making photocopies) users should contact the information service of the IISH (e-mail: vid@iisg.nl). 


\title{
I. Persons
}

\author{
Abendroth, Wolfgang (1906-1985) \\ Period: c.1918-I933, I937-I94I, I945-1967, I988, 2000 \\ Size: $1.25 \mathrm{~m}$. \\ Finding aid: inventory \\ Accrual: for initial descriptions see GIA, pp. 24-26.
}

Letters from his period in Gestapo- und Untersuchungshaft to his family 1937, and from the Zuchthaus Luckau to his family I937-I94I; documents regarding his stay in prison I937, I940; notes from Elisabeth Abendroth on the prison letters by Wolfgang Abendroth 1988, 2000; notes on the Arab, Italian, Persian, and Spanish languages c.1938-I940. Miscellaneous correspondence I954-I955, I957-I964; lectures, papers, and typescripts by others and other documents acquired as director of the Institut für wissenschaftliche Politik in Marburg 195I-196I; typescripts, including Sozialgeschichte der europäischen Arbeiterbewegung 1953-1965; files on his membership of state courts I952-1962; on his membership of the Deutsche Rat der Europäischen Bewegung I949-I950, and the Vereinigung für die Wissenschaft von der Politik I95I-I955, I960; file on the International Political Science Association (IPSA) Freudenstadt Round Table Meeting 1962; file on the relation between SDS and SPD 1959; congress and conference documents of the Internationale der Kriegsdienstgegner (IdK) I96I-I963; legal pamphlets and offprints I95I-I952, I96I-I963; newsletters 1953-I966; documentation on economical democracy c.19i8-1933, on the Deutsche Friedens-Union 1960-1963, and other documentation and printed material I930, I945-I947, I950-I952, I956, I958, I96I-1967.

\section{*Ammers-Douwes, Jeanne J. van (born 1944) \\ Period: $198 \mathrm{I}-\mathrm{I} 999$ \\ Size: $0.25 \mathrm{~m}$.}

Accrual: for initial description see GIA over 2000, p. 322.

Correspondence and documents from Amnesty International on the Estonian political prisoner Arvo Pesti i983-1987, on the Indonesian political prisoners Gatot Lestaryo, Djoko Untung, Rustomo and Yakobus Eko Kurniawan I985, I996-1999, and on the East Timor political prisoner Filomena da Silva Pereira Ferreira I99II996; some documents on human rights in Indonesia and Uruguay I98 I, I99I.

\author{
Bourseiller, Christophe (born I957) \\ Period: 1960-2000 \\ Size: $2.5 \mathrm{~m}$. \\ Finding aid: list
}

Accrual: for initial description see GIA over 2000, p. 323.

Documents concerning Maoist and Marxist-Leninist groups and parties in France and other countries; journals, internal documents, pamphlets, brochures etc. of the Parti Communiste Marxiste-Leniniste de France, the Parti Communiste des Ouvriers de France and others 1963-i999. 


\section{Craipeau, Yvan (I9II-200I) \\ Period: I96I-200I \\ Size: $0.37 \mathrm{~m}$.}

Born in Roche-sur-Yon (Vendée), France I9I I, died in Paris 200I; Trotskyist activist; joined a Trotskyist group in Paris in 1929; became leader of Trotskyist periodicals and youth groups and personal secretary of Trotsky i935; was involved in the Parti Communiste Internationaliste (PCI) of which he was general secretary 1946-1948; separated with his tendancy from the PCI in I948; became teacher in Guadeloupe from I95 I-I954; from I 954 he participated in several leftwing communist groups; wrote several books on Trotskyism.

Correspondence I962, I970-200I; manuscripts of articles and books I96I, I968I 970, I984, I994-200I; documents concerning a history project in Taverny about the people of Taverny during the Revolution of 1789 , including two letters of the Revolutionary period; prints of articles by Craipeau.

\section{Darsono Notosudirdjo, Raden (I893-I976) \\ Period: $1945-1975$}

\section{Size: $0.03 \mathrm{~m}$.}

Born in Pati, Java I 893, died in Semarang, Java 1976; journalist and editor of 'Sinar Hindia' I92 I; propagandist of Sarekat Islam; member, later President of the Partai Komunis Indonesia (PKI, Indonesian Communist Party) from 1920-1925; journeyed through Siberia to Western Europe in I92 I-I923; represented the PKI at the third Congress of the Comintern in Moscow I92I; remained abroad for nearly two years, during which he worked for several months at the Comintern's bureau in Berlin; spoke at a congress of the Dutch Communist Party in Groningen I92 I; returned to Moscow 1922 and afterwards to Indonesia I923; arrested 1925 and expelled from Indonesia 1926; by way of Singapore and China he returned to Soviet Russia where, under the pseudonym of Samin, he worked for the Comintern; elected alternate member of the ECCI 1928; expelled from the Comintern 193 I; went to the Netherlands 1935; returned to Indonesia I950; after breaking with communism became advisor at the Indonesian Ministry of Foreign Affairs until 1960.

Letters from Raden Darsono Notosudirdjo to his son Alam Darsono and Pop Stam, the wife of Alam Darsono I945, I950-1975; letters from Raden Darsono to H. Rasjidi and Mohammad Hatta 1974; memoirs from and written interviews with Raden Darsono 1968.

\section{*Dvorkina, Majja Davidovna (born 1927) \\ Period: 2002 \\ Size: $0.01 \mathrm{~m}$. \\ Accrual: for initial description see GIA over 200I, p. 354.}

Typescript on the acquisition of the collection of the Allgemeiner Jüdischer ArbeiterBund by the former Institute of Marxism-Leninism IML in the period I924-I928, 2002. 


\author{
Karaman, Muharrem (born 1938) \\ Period: 1957-1999 \\ Size: $5 \mathrm{~m}$.
}

Finding aid: list

Born in (Akcadag) Malatya, Turkey 1938, emigrated to Belgium in 1964; learned French and was trained as social worker; coalminer, union representative; chairman of the Centre Turc d'Information, d'Animation Culturelle et d'Aide Sociale (Turk-Danis); member of the National Assemble of the Confederation des Syndicats Chrétiens (CSC), and eventually the head of the Turkish Department of the same union; between 1979-1994 representative of the CSC in the council of migrants of the Department of Culture; retired in I994.

Documents relating to his activities for the Confédération des Syndicats Chrétiens (CSC) 1973-1997, the Centre Turc d'Information, Animation Culturelle et d'Aide Sociale (Turk-Danis) 1973-1997, concerning the coup d'état in Turkey on I 2 September 1980 and the trial against the Türkiye Devrimci İsçi Sendikaları Konfederasyonu (DISK) I974-1987, documents on the support by the European Trade Union Confederation (ETUC) of DİSK 1979-1986, Migrants' Forum of the European Union 1977-1997, Comité Belge pour la Démocratie en Turquie (Belgian Committee for Democracy in Turkey) I980-1989, Avrupa Türkiye Toplumu Konseyi (ATTK) I989-I996; documentation on Turkish migrants in Belgium, human rights in Turkey and Turkish labour I957-1997.

\title{
Lowe, Martyn (born 1949) \\ Period: I99I-I999 \\ Size: $0.37 \mathrm{~m}$.
}

Born in London 1949; pacifist activist; active in the Peace Pledge Union since 1968, within Greenpeace (London) and since 1985 volunteer with the WRI international secretariat; member of the Editorial Board of the Information for Social Change, and with Declan Mc Hugh founder of the Librarians within the Peace Movement 1989; Information for Social Change is an activist organization that examines issues of censorship, freedom, and ethics amongst library and information workers; it is committed to promoting alternatives to the dominant paradigms of library and information work and publishes its own journal Information for Social Change.

Letters and other documents regarding issues of censorship, freedom and ethics in various countries, received by Information for Social Change 1993-1998; documents regarding Librarians within the Peace Movement I99I-I993; documents regarding the Library and Information Workers Organisation (LIWO) in South Africa and its newsletter Liwolet I99I-1999.

\section{Müller, Karl Fritz Max (I917-2000) \\ Period: $1933-1977$ \\ Size: $0.03 \mathrm{~m}$.}

Born in Leipzig 1917, died 2000; member of the Kommunistische Partei Deutschlands (KPD); prisoner in Nazi Germany; public prosecutor in the German Democratic Republic.

Three postcards I933-I935; copies of letters by Müller from prison to his parents I934-I935; membership booklets of Müller and his wife Edith Müller of the Freier Deutscher Gewerkschaftsbund (FDGB), the Gesellschaft für Deutsch-Sowietische 
Freundschaft and the Vereinigung der Juristen der Deutschen Demokratischen Republik 1955-I977; autobiographical notes n.d.

\section{Novikov family \\ Period: 1928, 1992 \\ Size: $0.04 \mathrm{~m}$.}

Accrual: for initial description see GIA, p. I6r.

Typescript of Rodnik. Povest' ob Ivane Novikove - pisatel' i celoveke, biography of the writer Ivan A. Novikov (I878-1959) by Marina Novikova and Jakov Volkov I959-1992; letter of D. Nekrasov to Aleksandr A. Novikov 1928.

\section{Sainte-Laigue, André (1882-1950) \\ Period: $1931-1938$}

Size: $0.12 \mathrm{~m}$.

Born in Saint Martin Curton in Lot-et-Garonne, France I882, died I950; studied mathematics; served as a soldier and was wounded during the First World War; professor in mathematics and its applications at the Conservatoire National des Arts et Métiers (CNAM) 1938-1950; president of the Confédération des Travailleurs Intellectuels 1929-I950.

Correspondence and other documents regarding the Confédération Générale du Travail (CGT), the Compagnie d'Organisation Rationelle and the Chantiers Coopératives and other cooperative organizations I93 I-1935; press clippings 1935.

\section{Sarrau Royes, Liberto (1920-200I) and Joaquina Dorado Pita (born 1917) \\ Period: 1943-2001}

Size: c. $2.5 \mathrm{~m}$.

Liberto Sarrau Royes: anarchist, was born in Fraga, Spain 1917, died in Paris 200I; born into an anarchist family; attended a school in Barcelona ran by the textile syndicate of the CNT; formed an anarchist youth group 1936; fought in the civil war in 1937; fled to France 1939; lived in Morocco and France; caught in 1948 while conducting anti-franquist agitation in Spain and sentenced to twenty years of imprisonment; fled again to France during a probational leave in 1958; tried to organize actions in Spain and revive the anarchist organizations; active in the Movimento Popular de Resistencia (MPR); worked as journalist for papers of the CNT in exile; co-founder of the Asociacion Cultural y Ecologica 'Natura' (ACEN), which aimed at establishing a permanent libertarian summer camp Mon-Nou (New World) in the Pyrenees. Joaquina Dorado Pita: born in La Coruña 1917; moved to Barcelona in 1934; member of the carpenters' and upholsterers syndicate; involved in the resistance against Franco; fled to France 1939; participated in reconstructing the anarchist syndicates in France, together with Liberto Sarrau; conducted anti-franquist agitation in Spain; caught and imprisoned; provisionally released in 1949 but caught again in 1950; finally released in 1957; lives in France and since 1990 alternately in Barcelona.

Papers of Liberto Sarrau Royes: correspondence I943- I999; documents concerning the MPR I958-1964, theatre and film projects I970, ACEN and MON-NOU I989I995, CNT and FAI 1946, I989; manuscripts and articles by Liberto Sarrau; documentation, copies of Obra Mercedaria, magazine for (political) prisoners I947- 
I952, of Boletin de Información of the MPR, of Bulletin d'information of CARE (Comité d'Aide de la Résistance Espagnol).

Papers of Joaquina Dorado Pita: correspondence I958-200I.

\author{
Soepardjan, Adam (born 1927) \\ Period: 1973-2002 \\ Size: $0.25 \mathrm{~m}$. \\ Finding aid: list
}

Pseudonym: Bintang Karim; born on Sumbawa, Dutch East Indies, 1927; during the Japanese occupation labourer in New Guinea from 1942-1945; sergeant-major with the Indonesian marines in 1945; arrested and imprisoned by Dutch troops from 1948-1949; went to Surabaya after the transfer of sovereignty to Indonesia I949; worked with 'De Vrije Pers'; warehousehand at a Surabaya paint factory (PAR), where he became involved in the trade-union movement; secretary of the trade union Serikat Sekerdja PAR; board member of the Sarekat Buruh Industri Metal (Union of Metalworkers); SOBSI delegate to Europe, visiting among others the German Democratic Republic and Czechoslovakia 1959; political prisoner without trial detained in the Kalisosok prison in Surabaya 1965-1978; after his release foreign language teacher in English, German, and Dutch at Adam College in Surabaya.

Manuscript and typescript 'Kuncup mekar di Timur' by Adam Soepardjan on his fortunes in New Guinea in the period I942-1945 and parts of a translation; correspondence with Frits van den Bosch; correspondence by Van den Bosch with publishers I974-2000; letters by Soepardjan to Karel and Winnie Bernecker in 's-Hertogenbosch I99I-I999; manuscript 'My Reading (Travel Abroad)' II and III by Bintang Karim I975-I976; manuscript 'Mendobrak penjara rezim Soeharto' by Adam Soepardjan 2002; documents on the process against and the fate of some Indonesian political prisoners I992-200I.

\title{
*U Oung Myint Tun (1934-200I) \\ Period: $1988-1996$ \\ Size: $0.02 \mathrm{~m}$.
}

Deputy head of the Burmese section of the BBC World Service; activist for democracy and democratic socialism.

Documents regarding the 1988 movement for democracy, typescripts of interviews on behalf of the BBC World Service and speeches by U Oung Myint Tun on this period and on democratic socialism in Burma in the periods I948-1962 and I988I996.

\section{*Zitzlaff, Wienke (born I93I) \\ Period: 1962, 1968-1996 \\ Size: $4 \mathrm{~m}$.}

Born in Germany I93 I; grew up in a vicarage with her younger sister, the later member of the Rote Armée Fraktion (RAF), Ulrike Meinhof, who was arrested for murder in 1972 and died in prison in 1976; campaigned for the rights of handicapped people and became a teacher and headteacher of a special school; together with other relatives of RAF prisoners she became a fighter for more humane conditions in prisons, for visiting rights and against detention in 
isolation; she tried to obtain custody of the two daughters of Ulrike (both born 1962); later cofounder of the Sappho-Stiftung, an initiative for alternative housing projects for elderly lesbian women, and after her retirement worked as a volunteer in an international women's café.

Documents concerning the attempt of Wienke Zitzlaff to obtain custody of the children of Ulrike Meinhof I970-I97I; some letters from Ulrike to Wienke 1972 and n.d.; correspondence, photocopies of documents and documentation on the trials against RAF and supposed RAF members and of court cases in Germany, for the European Committee in Strasbourg, France, and the UN Commission on Human Rights in Geneva, Switzerland, on changes of prison conditions, on torture and on repression 1972-1990, I992; photocopies of the official death report and investigation, texts of funeral speeches, correspondence, minutes of meetings and press statements of the International Investigation Committee to clarify the circumstances surrounding the death of Ulrike Meinhof, of the solidarity group of relatives of political prisoners in the $\mathrm{BRD}$, and of the International Commission for the protection of prisoners and against conditions of isolation 1976-1983; correspondence concerning visits to and documentation on trials of individual prisoners 1976-198I, with correspondence with Gabrielle Kröcher-Tiedemann and Christian Möller I977-1985, and some letters by others to Jan-Carl Raspe, with photos I976-I977; some other correspondence I988I996; documentation on RAF, Baader-Meinhof-Gruppe and the trials, on prison conditions of other political prisoners, also in France, Italy, and Spain, and on imperialism I968-I996; correspondence by her husband Dietrich Zitzlaff concerning his report of a politically incriminating article about his career as a teacher 1962.

\section{Organizations}

\section{* Amnesty International (AI)}

Period: (1963-) 1989-2000 (-2002)

Size: $48 \mathrm{~m}$. (and I 3 I microfilms)

Accrual: for initial description see GIA, pp. 245-247.

Papers of the International Executive Committee (IEC) I994-2002, minutes of the IEC 1963-I980; outgoing documents send to sections ('AI Indexed Documents') in English 1989-1994, in French (1975-) 1989-1999, in Spanish (1963-) 1989-1999, in Arabic (1983-) I990-I997; Amnesty publications I991, I998-2000.

Microfilms of country research files on Colombia, Chile, Angola, South Africa, Yemen, Algeria, Morocco, Tunisia, Lebanon, Israel, Libya, China, India, Bulgaria, Poland, Romania, France, Italy, Turkey, Spain (1963-) I988-i997; files on prisoners of conscience in Angola, Kenya, Sudan, Zambia, South Africa, Tanzania I990; 'AI Indexed Documents' in English 2000-2001, French I998-1999, Spanish I 998. 


\title{
*Burma Action Group (BAG) \\ Period: (1978-) 1989-2000 \\ Size: $5.5 \mathrm{~m}$. \\ Finding aid: list
}

The Burma Action Group (BAG), founded January r991 by a group of Burma scholars and individuals; many of the founder members worked with students and other refugees on the Thai-Burma border; they wanted to continue and extend the Amnesty International campaign in Burma which ended in April 1991; the group campaigns for human rights and democracy in Burma, for a peaceful solution in the civil war and for the promotion of humanitarian aid to the people of Burma; in 1999 the Burma Action Group was renamed Burma Campaign UK (BCUK).

Correspondence with governments, Burma groups in various countries; meetings; documents concerning actions and events; documentation on politics, economics, ecology, foreign relations, minorities, refugees, humanitarian issues, travel and tourism in Burma, and Burma groups and organizations (1978-) I989-2000.

\section{Campaign for the Defence of the Turkish Peace Association \\ Period: 198 I - I 997}

\section{Size: $2.12 \mathrm{~m}$.}

Seventeen months after the military coup of 1980, on 26 February 1982, the entire executive committee and the founders of the Turkish Peace Association (Barış Derneği) were arrested; among the arrested were Mahmut Dikerdem, former ambassador and chairman of the association, Burhan Apaydın, president of the Istanbul Bar Association and other well-known intellectuals; their arrest and trial activist caused a wave of outrage in international public opinion; the Campaign for the Defence of the Turkish Peace Association was founded in $198 \mathrm{I}$ in London to mobilize support amongst British, American, and European peace movements; one of the founders was Mehmet Ali Dikerdem, M.A., D.Phil. Lecturer at the University of Middlesex and the son of Mahmut Dikerdem.

Collection on the activities of the Campaign for the Defence of the Turkish Peace Association: correspondence with the imprisoned peace activists, parliamentarians including Neil Kinnock, Michael Foot, and Tony Benn, organizations including Amnesty International, International PEN, and European Nuclear Disarmament, prominent personalities including Harold Pinter, Arthur Miller, Erdal Inönü, and Behice Boran 1982-1987; documents concerning the trail and sentence of the Turkish Peace Association I98I-1986, other solidarity campaigns with the Turkish intellectuals and trade unionists 1982-1985; reports from Amnesty International, Helsinki Watch, and the European Parliament on human rights and democracy in Turkey 1982-1997.

\author{
Kommunistische Partei Deutschlands-Opposition KPD (O) \\ Period: $1935-1948$ \\ Size: $0.05 \mathrm{~m}$. \\ Finding aid: list
}

Kommunistische Partei Deutschlands (Opposition); founded in 1928 by former KPD officials Heinrich Brandler and August Thalheimer, since 1930 partly working from an office abroad 
(Auslandskomitee), in an international context (Internationale Vereinigung der Kommunistischen Opposition, IVKO) and in exile.

Pamphlets regarding activities and points of view of KPD $(\mathrm{O})$ and IVKO, mainly meant for discussions within the party 1935-1939; bulletin Internationale monatliche Übersicht by August Thalheimer 1946-1948.

\section{Organizing Committee Chittagong Hill Tracts Campaign (OCCHTC)}

Period: $1986-2002$

Size: $1 \mathrm{~m}$.

Accrual: for initial description see GIA, pp. 3I4-3is.

Correspondence; minutes of meetings; documents concerning conferences and other activities I986-1995.

\section{SA/NAM Association}

Period: $1986-1993$

Size: $6.75 \mathrm{~m}$.

Finding aid: list

The SA/NAM Association (South Africa/Namibia Association) was founded in 1986 and dissolved in 1992, together with the end of the apartheid regime in South Africa; seated in Brussels, it was concerned with coordinating, stimulating, and monitoring development projects in South Africa and Namibia, which were initiated by its member organizations.

Minutes of meetings, correspondence, financial and other documents relating to activities of NGOs in South Africa and Namibia I988-1992; files of projects conducted by the Kagiso Trust in South Africa; documentation.

\section{*United for Intercultural Action \\ Period: 1993-2002 \\ Size: $3.12 \mathrm{~m}$ \\ Finding aid: list \\ Accrual: for initial description see GIA over 200I, pp. 363-364.}

Documents relating to conferences organised by United for Intercultural Action, with correspondence, documents concerning preparation, subventions, participants, and accommodation 1993-1998; documentation from European antifascist and antiracist organizations.

\section{*War Resisters' International (WRI) \\ Period: 1977-2000 \\ Size: $3.75 \mathrm{~m}$}

Finding aid: list

Accrual: for initial description see GIA, p. 343 and GIA over 1999, pp. 373-374.

Documents concerning the Triennial Conferences I986-I994, the annual council meetings I988-1997; 'daily files' with correspondence I993-2000; files concerning 
conscientious objection I977-1998; documents concerning sections, the Balkan Peace Team I993-2000; notebook written by Myrtle Solomon I98 5.

\section{Subjects}

Social and political movements in the Philippines

Period: $1972-2002$

Size: $3.37 \mathrm{~m}$.

Finding aid: list

Documentation concerning the political background, political movements, antiMarcos dictatorship, elections, labour, trade unions, peasants, overseas workers, indigenous people, women, religious movements, social movements, culture, environmentalism, agitation against American bases, and nuclear arms 1972-2002. 